\title{
Eimeriosis in capybaras (Hydrochaeris hydrochaeris) in the state of Rio Grande do Sul, Brazil
}

\author{
ANA CLÁUDIA FAGUNDES GURGEL*, AMANDA DOS SANTOS SARTORI** \\ and FLÁVIO ANTÔNIO PACHECO DE ARAÚJO***
}

\begin{abstract}
Capybaras are the largest of living rodents and are the most common wild rodent in the state of Rio Grande do Sul, Brazil. They are commercially bred for their meat, hide, and oil. The present study aims to shed some light upon intestinal protozoa of capybaras using Sheather's method modified by Benbrook to analyze 250 fecal samples. The following Eimeria species were detected000 in 52.4\% of the fecal samples: E. trinidadensis, E. ichiloensis, E. boliviensis, in addition to another species that could not be identified. With regard to the total oocyst count, the relative frequency of different Eimeria species was as follows: E. trinidadensis (55\%), E. ichiloensis (32.6\%), E. boliviensis (4.8\%), and an unidentified Eimeria species (7.6\%). The unidentified species was called Eimeria araside sp.n. (Apicomplexa: Eimeriidae).
\end{abstract}

Key words: capybara, Eimeria, faeces.

\section{INTRODUCTION}

Capybaras are relatively frequent in several regions of the state of Rio Grande do Sul, Brazil, and along with coypus (Myocastor coypus), according to a recent study carried out with six families of wild rodents, were considered to be the most abundant type of rodent in the state of Rio Grande do Sul ${ }^{1}$.

The experience of more industrialized countries in the rearing and exploitation of capybaras has shown that their hide is widely used for the manufacture of gloves, shoes, belts, etc $^{2}$, with a great potential for the production of meat and oil ${ }^{3}$.

Eimeriosis is a contagious catarrhal enteritis that affects the small and/or large intestine and is caused by different Eimeria species ${ }^{4}$. It usually occurs among young animals, whereas successive infections in adult animals make their body develop a resistant immune system, turning them into carriers of the disease ${ }^{5}$.

Unsporulated oocysts consisting of a nucleated protoplasmic mass wrapped by a resistant wall are passed in the feces. Under appropriate oxygen conditions, high humidity and ideal temperatures (of approximately $27^{\circ} \mathrm{C}$ ) and within two to four days, oocysts sporulate and become infective ${ }^{6}$.

The clinical diagnosis of eimeriosis is established by the following signs: sudden onset of bloody diarrhea, accompanied by dehydration,

\footnotetext{
* Master Student at PPGCV. Faculdade de Medicina Veterinaria. Universidade Federal do Rio Grande do Sul. Av. Benito Goncalves, 9090. CEP 91540-000, Porto Alegre, RS, Brasil.

** Scholarship Holder of FAPERGS Grant.

*** Laboratorio de Protozoología. Facultade de Medicina Veterinaria. Universidad Federal Rio Grande do Sul, Brasil.
} 
weight loss, loss of appetite, lethargy, and sometimes, death. The laboratory diagnosis is made by coproparasitological analysis, with Sheather's method being the most widely used technique, and also by necropsy, which takes macroscopic and microscopic lesions into consideration ${ }^{7}$.

According to Carini ${ }^{8}$, two new Eimeria species have been found in capybaras: $E$. capibarae and E. hydrochoeri.

\section{MATERIAL AND METHODS}

The capybaras were from the zoo in Sapucaia do Sul, from a privately-owned rearing station in Santo Antônio da Patrulha and from an experimental center (CEULBRA - Centro Experimental da Universidade Luterana do Brasil), located in the town of Montenegro. In these places, animals of different ages lived together. A total of 250 fecal samples were collected from the rearing stations. The samples were collected at an interval of approximately 30 days. Freshly shed feces were collected from the ground, placed in plastic vessels, kept on ice and taken to the Laboratory of Protozoology at FAVETUFRGS. At the laboratory, the samples were kept in a refrigerator at approximately $8^{\circ} \mathrm{C}$, for later processing.

The samples were collected between February and August 2004 and the study was completed in March 2005.

The fecal samples were submitted to Sheather's method modified by Benbrook, based on the study by Hoffmann ${ }^{9}$, used to detect Eimeria spp. After the detection of Eimeria oocysts through this method, they were submitted to ocular micrometry. The aim of this method was to measure the length and width of oocysts and then to identify them. These data, coupled with morphological characteristics, allowed classifying the species found in the experiment.

Afterwards, the unsporulated oocysts were protographed at x100 and x400 magnification and sporulated in $2.5 \%$ potassium dichromate. Sporulation occurred on the 25th day and the sporulated oocysts were photographed again at x100 and x400 magnification.

\section{RESULTS AND DISCUSSION}

The genus Eimeria was detected in $52.4 \%$ of fecal samples of the analyzed capybaras, and four species were found: E. trinidadensis (55\%), E. ichiloensis (32.6\%), E. boliviensis (4.8\%) and $E$. araside $(7.6 \%)$.

Table 1 shows the occurrence (\%) and the micrometric parameters of oocysts (mean \pm standard deviation) of different Eimeria species found in capybaras, in Santo Antônio da Patrulha, Montenegro and Sapucaia do Sul, state of Rio Grande do Sul, Brazil.

The oocysts classified as E. araside had the following morphological characteristics: ellipsoidal oocyst of uniform thickness consisting of two layers: a very smooth and well-delineated, dark brown outer layer, and a homogeneous inner layer. No micropyle, micropylar cap and oocyst residuum were observed (Figure 1).

Moreno et $\mathrm{al}^{10}$, carried out a study about gastrointestinal parasitism of capybaras in Venezuela, where $41.7 \%$ of 84 fecal samples were positive for Eimeria spp, yielding similar results to the present study (52.4\%).

Table 1. Occurrence (\%) and micrometric parameters of oocysts (mean \pm standard deviation) from different Eimeria species found among capybaras in Santo Antônio da Patrulha, Montenegro and Sapucaia do Sul, in southern Brazil

\begin{tabular}{|c|c|c|c|c|}
\hline \multirow[t]{2}{*}{ Species } & \multirow[b]{2}{*}{ Length } & \multicolumn{2}{|c|}{ Oocysts (mean \pm standard deviation) } & \multirow[b]{2}{*}{ Occurrence (\%) } \\
\hline & & Width & Morphometric index & \\
\hline E. trinidadensis & $20.79 \pm 1.57$ & $20.79 \pm 1.57$ & $1.15 \pm 0.1$ & 55 \\
\hline E. ichiloensis & $25.08 \pm 1.88$ & $25.08 \pm 1.88$ & $1.26 \pm 0.1$ & 32.6 \\
\hline E. boliviensis & $32.42 \pm 2.91$ & $24.87 \pm 2.08$ & $1.31 \pm 0.17$ & 4.8 \\
\hline E. araside & $18.56 \pm 2.51$ & $15.3 \pm 0.92$ & $1.22 \pm 0.19$ & 7.6 \\
\hline
\end{tabular}




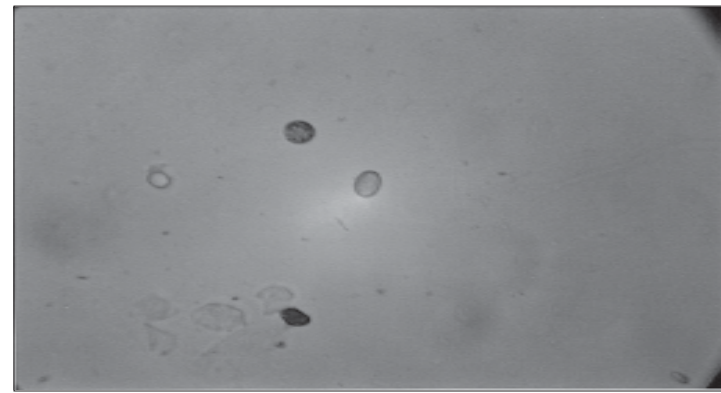

Figure 1. Unsporulated oocyst of Eimeria araside, at the center of the slide, detected in capybaras by Sheather's method (x400).

Authors reported three new Eimeria species in capybaras in Bolivia and Venezuela: E. trinidadensis, E. ichiloensis and E. boliviensis ${ }^{11}$. They found an occurrence of $76 \%$ and $37 \%$ for E. trinidadensis in Bolivian and Venezuelan capybaras, respectively ${ }^{11}$. The same authors found an occurrence of $86 \%$ and $84 \%$ for E. ichiloensis in Bolivian and Venezuelan capybaras, respectively, which differs from the results obtained in the present study (32.6\%). In Venezuela, they found an occurrence of $26 \%$ of E. boliviensis in Bolivian capybaras and of $26 \%$ in Venezuelan capybaras, which differs from the results herein $(4.8 \%)^{11}$.

According to Casas et $\mathrm{al}^{11}$, E. trinidadensis resembled $E$. hydrochoeri, found in some Brazilian animals, as they had the same size, despite different morphological characteristics ${ }^{8}$. According to these authors, E. ichiloensis resembled E. capibarae, found by $\mathrm{Carini}^{8}$ in some Brazilian capybaras, since they had the same morphological characteristics, but were of different sizes.

The present study revealed an oocyst type that belongs to an Eimeria species not yet described in the literature, which was therefore first described in the present study.

The new species, E. araside sp.n. (Apicomplexa: Eimeriidae), was named after the three researchers who first described this type of Eimeria $^{12}$.

The lack of similar studies in the literature does not allow for a more in-depth analysis. However, the present study is a starting point for future studies on protozoa in the feces of capybaras.

Our conclusion is that capybaras are susceptible to Eimeria spp., with three species being identified: E. trinidadensis, E. ichiloensis and $E$. boliviensis. One of the species was not identified because its size did not match any species portrayed in the literature, so a new species called E. araside sp.n. (Apicomplexa: Eimeriidae) was described.

\section{REFERENCES}

1.- SILVA F. Mamíferos silvestres - Rio Grande do Sul. 2. ed. Porto Alegre: Fundação Zoobotânica do Rio Grande do Sul 1994; 7: 246.

2.- SILVA L F. Criação de capivaras em cativeiro. São Paulo: Nobel 1986; Cap. 14, p. 62-5.

3.- SILVA NETO, P.B. Criação racional e comercial de animais silvestres. J. SOS Mata Atlântica, São Paulo, 1995; 7, n. 2, p. 3.

4.- SILVA $\mathrm{N} R \mathrm{~S}$, CHAPLIN E L, KESSLER $\mathrm{R} H$. Protozooses dos animais domésticos. Porto Alegre: UFRGS, 1980; 220p.

5.- CARDOSO S B. Protozoologia veterinária. Fortaleza: IOCE, 1986; $181 \mathrm{p}$.

6.- URGUHART G M, ARMOUR J, DUNCAN J L, et al. Parasitologia veterinária. $2^{\mathrm{a}}$ ed. Rio de Janeiro: Guanabara Koogan, 1998; 273 p.

7.- FORTES E. Parasitologia veterinária. 4. ed., ver. ampl. São Paulo: Ícone 2004; 607 p.

8.- CARINI A. Sur Deux Nouvelles Eimeria D' Hydrochoerus Capibara. Ann Parasitologie 1937; 15: 367-9.

9.- HOFFMANN R P. Diagnóstico de parasitismo veterinário. Porto Alegre: Sulina, 1987; 156 p.

10.- MORENO L G, LORD R, MORALES G, et al. Parasitismo gastrointestinal de Hydrochaeris hydrochaeris en un hato del Estado Apure- Venezuela. Vet Trop 1999; 24: 85-91.

11.- CASAS M C, DUSZYNSKI D W, ZALLES L M. Three new Eimerians in capybara (Hydrochaeris hydrochaeris) populations from Eastern Bolivia and Southern Venezuela. J Parasitol 1995; 81: 247-51.

12.- ARAUJO F A P, SILVA N R S, DENICOL A C. Identificação de protozoários parasitos intestinais de capivaras. In: SALÃO DE INICIAÇÃO CIENTÍFICA, 2001, Porto Alegre, RS. Anais do XIII Salão de Iniciação Científica da Universidade Federal do Rio Grande do Sul, 22 a 24 de outubro 2001, ESEF- Campus Olímpico. Porto Alegre: Universidade Federal do Rio Grande do Sul, 2001. Sessão 4 (Biodiversidade e Ecologia Animal) em Ciências Biológicas, trabalho 029. p. 252. 